\begin{tabular}{|c|c|}
\hline . & $\begin{array}{l}\text { Jurnal Penelitian dan Evaluasi Pendidikan } \\
\text { Volume 23, No 2, December } 2019 \text { (106-116) }\end{array}$ \\
\hline in $d z$ & Online: http://journal.uny.ac.id/index.php/jpep \\
\hline
\end{tabular}

\title{
EVALUATION OF ISLAM EDUCATION TEACHERS TRAINING IMPLEMENTATION
}

\author{
Helen Sabera Adib \\ Universitas Islam Negeri Raden Fatah \\ Djemari Mardapi \\ Universitas Negeri Yogyakarta \\ Zamroni \\ Universitas Negeri Yogyakarta \\ Adam Jait \\ Universiti Islam Sultan Sharif Ali
}

\begin{abstract}
The purpose of this study is to evaluate the implementation of the Islam education teachers' training in the Religion Education and Training Center in Palembang. This study is an evaluation research conducted using the Islam Education Teachers Training model, which consists of Context, Input, Process, and Product aspects. Sources of information in this study include the training organizers, Widyaiswara (civil servants assigned as instructors), and the participants of the training. Data collection was conducted using questionnaires, observation, and documentation. The data analysis technique used in this study was quantitative descriptive. The results of the study conclude that the implementation of the Islam Education teachers' training program is very successful, as shown by the success indicators in terms of context, input, process, and product aspects.
\end{abstract}

Keywords: evaluation model, teacher training, Islam education

Permalink/DOI: http://dx.doi.org/10.21831/pep.v23i2.20986

\section{Contact: Helen Sabera Adib}

oxaliscrgirlgmail.com

Department of Islam Education, Faculty of Tarbiyah and Educational Science, Universitas Islam Negeri Raden Fatah

Jl. Prof. K.H. Zainal Abidin Fikri Km. 3,5, Pablawan, Kemuning, Palembang, South Sumatera 30151, Indonesia 


\section{Introduction}

Assessment in the education curriculum with all its problems is an interesting topic to discuss. The most widely discussed topic in education is the teacher. Teachers are professional educators who must have a variety of abilities or competencies that are needed to carry out their educating tasks. Law No. 14 of 2005 of the Republic of Indonesia on teachers and Widyaiswara article 8 paragraph (1) stipulates four types of competencies that must be possessed by teachers, namely pedagogical competence, personal competence, social competence, and professional competence.

Teachers are important in the teaching and learning system so that they have to be able to combine these two things well. The first thing is that teachers must always update their knowledge and abilities in teaching. The second thing is that teachers must equip themselves with the competencies needed and behave positively to do their profession (Bhargava \& Pathy, 2011). Teachers are required to be able to convey the lesson well so that students can absorb the lesson well, meaning that teachers are required to have good communication competence. If the teachers play their roles well, then the target of teaching and learning will be achieved because the learning process in the class determines the quality of the school, and teachers are the determining keys for the high or low quality of the school (Ilukena, 1998).

The results of the teacher competency test indicated that the teachers' competency level is still low. There is no significant difference between the teachers' professional competence and the senior level teacher training college students' professsional competence. The teacher pedagogical competence test results also showed less encouraging results. The average ability of teachers in planning lessons, especially in formulating learning indicators, organizing materials, determining learning resources, creating learning scenarios, and ways of assessing students still need to be improved. The weakness lies in the way teachers assess students (Research Center for Educational Policy and Innovation, 2007, pp. 57-58).

Suraji (2010), in the results of his study, states that the pedagogical, personal, and social competence of Madrasab Ibtidaiyah teachers in Pekalongan is still not optimal. The results of another study (Zainuri, 2012, p. 3) also explain that the competency of State Madrasab Ibdtidaiyah teachers in Palembang still needs to be improved because it is still low. Government efforts to improve the teachers' competence have been carried out by implementing teachers' training programs. The training was not only conducted by the Ministry of National Education but also carried out by the Ministry of Religious Affairs as well as by many other government institutions. The training was carried out in order to increase the teachers' competence.

Teacher training is a form of inservice education for teachers. Training is an activity that is carried out to improve the quality of teachers and acts as a program that helps teachers understand and implement educational policies that are directly related to the teachers' task. The training program aims to equip and improve teachers' abilities and competence. Teachers who have participated in the training program are expected to be able to apply the abilities that they obtain from the training, meaning that after the training, there will be an improvement in the quality of teachers and changes in the form of better learning behavior. Herzberg, Mausner, and Snyderman (2010) state that training is a learning process to improve the teaching ability of teachers to carry out their tasks in the future.

The purpose of the training is to improve the quality of teachers, which in this case are the Islam education teachers, which can be pursued through the Islam education teachers training program that is organized by the education and training organizers, one of which is the religious education and training center. Susatya (2013, pp. 107-108) states that high-quality education and training centers can produce superior, strong, high-tech human resources 
who have adequate competence so that they are able to compete with other countries' human resources. Islam education teachers' training is carried out to equip the Islam education teachers to become qualified, strong, and superior teachers.

According to Notoatmodjo (1991, p. $53)$, the implementation of the training program can be said to be successful if a transformation process occurs within the training participant in the form of increased ability to carry out tasks and changes in behavior which are reflected in their attitudes, discipline and work ethic. The changes and improvements can be seen if an assessment or evaluation of the implementation of the training program is carried out.

Goldstein and Ford (2002, p. 110) state that the readiness to learn, the background of the field of work, and the learning motivation of the participants are decisive in achieving the benefits of the training. Adults are ready to learn when they know that they need to learn about something that is usually related to the problem at hand, work assignments, or the desire to achieve something more in their lives (Knowles, 1980, p. 44).

Program evaluations produce information concerning the design, implementation, and assessment of the results of the efforts that have been made to solve the problems (McDavid \& Hawthorn, 2006, p. 3). Program evaluation results can be used as a benchmark to find solutions for the problems, and development can also become the basis in making decisions regarding the program. Evaluation of the training program becomes an important thing to do because it aims to find information about the success rate of the training. According to Arikunto and Jabar (2009, p. 5), program evaluation is an activity to find out how high the success rate of the program is, to find out whether the educational goals have been achieved, and the efforts to provide information to be conveyed to the decisionmakers.

The religious education and training center, as the agency in charge of the train- ing program, must have this evaluation tool to assess the success of the training. Besides, the evaluation process can be carried out by applying a suitable evaluation model. The evaluation model can be chosen according to the needs and focus of the evaluation, which is going to be conducted. The Islam education teachers' training program needs a comprehensive evaluation. An evaluation model may be suitable to evaluate a program, but it does not mean that it can meet the needs of other program evaluation implementation (Phillips, 1991).

The best evaluation model is an evaluation model that can evaluate the program according to the needs of the program. Based on the observations conducted at the religious education and training center in Palembang, an Islam education teachers' training program was carried out. The training program aims to improve the competence of Islam education teachers. However, there has been no suitable evaluation model and evaluation instruments used specifically to evaluate the implementation of the program. Therefore, Islam education teachers' training evaluation model becomes an alternative to solve the problem. This study aims to evaluate the implementation of the Islam education teachers training program in the religious education and training center in Palembang by using the Islam education teachers' training evaluation model.

\section{Research Method}

This study is evaluation research conducted by applying the Islam education teachers' training (Pendidikan Guru Pendidikan Agama Islam or PGPAI) evaluation model. The PGPAI evaluation model consists of four components, namely context, input, process, and product. The source of information in this study was 43 people covering the training organizers, Widyaiswara, and the training participants. The purpose of this study was to evaluate the implementation of Islam education teachers' training in the religious education and training center in Palembang. 
On the other hand, the PGPAI evaluation model had been developed through the ten steps of model development (Borg \& Gall, 1993), which were then simplified into three steps, as suggested by Cennamo and Kalk (2005). The three steps of model development research included (1) the model pre-development stage, (2) the conceptual model for the field trials (model testing) development stage, and (3) the model application stage. As an illustration, the PGPAI evaluation model is described as follows.

The pre-development stage of the PGPAI evaluation model is the initial research stage, and the information collected was related to the evaluation system of the Islam education teachers' training at the religious education and training center in Palembang. The information was about the type of evaluation models that have been used so far. In addition, a theoretical review of the existing evaluation models was also carried out, as well as a review of the results of relevant studies. The result of the predevelopment stage was the initial model (prototype). This model refers to the CIPP evaluation model (Context, Input, Process, Product).

The conceptual model development stage was the stage of planning the model and assembling the PGPAI evaluation instruments. The design of the evaluation model involved six experts in the field of educational research and evaluation and the field of Islam education. In addition, the involvement of practitioners and academicians had also been carried out through the Focus Group Discussion (FGD) technique. Furthermore, content validation was conducted through expert judgment using the Aiken formula. The experts assessed the design of the model and the instruments as well as the equipment using the Delphi technique. The experts' assessments were used as the guideline to improve the materials before the models, instruments, and equipment were used. Based on expert judgment, the PGPAI evaluation model instrument was declared valid. It was con- cluded valid after conducting a review of the Aiken table, which showed that the $\mathrm{V}$ Aiken instrument achieved a score above 0.70. In addition, there were also expert judgments on the evaluation procedure, evaluation guideline, and the instruments' clarity. The results of the expert judgment indicated that the evaluation procedure, evaluation guideline, and the instruments' clarity were categorized as very good. The summary of the results of the expert judgment was presented in Table 1 and Table 2. The collected data were analyzed using quantitative descriptive analysis and then compared with the criteria that have been set in Table 3.

Table 1. Content Validity of the PGPAI Evaluation Model Instruments

\begin{tabular}{cccc}
\hline No & Component & V Aiken & Interpretation \\
\hline 1 & Context & 0.95 & Valid \\
2 & Input & 0.95 & Valid \\
3 & Process & 0.94 & Valid \\
4 & Product & 0.93 & Valid \\
\hline
\end{tabular}

Table 2. Expert Judgment

\begin{tabular}{ccc}
\hline $\begin{array}{c}\text { Assessment } \\
\text { Aspects }\end{array}$ & Average & Category \\
\hline Evaluation Procedure & 3.66 & Very Good \\
Evaluation Guideline & 3.54 & Very Good \\
Intrument Clarity & 3.46 & Very Good \\
\hline
\end{tabular}

Table 3. Scoring Category

\begin{tabular}{ccc}
\hline No & Score & Category \\
\hline 1 & $X \geq \bar{X}+1 . S B_{x}$ & Very Successful \\
2 & $X+1 . S B_{x}>X \geq \bar{X}$ & Successful \\
3 & $\bar{X}>X \geq \bar{X}-1 . S B_{x}$ & Less Successful \\
4 & $X<\bar{X}-1 . S B_{x}$ & Unsuccessful \\
\hline
\end{tabular}

Source: Mardapi (2012, p. 162)

Notes:

$X=$ Score

$\bar{X}=$ Average Score

$S B_{x}=$ Standard Deviation

\section{Findings and Discussion}

The study obtained some information about the implementation of the Islam education teachers' training in the religious education and training center in Palembang, 
which was evaluated using the PGPAI model consisting of the aspects of context, input, process, and product. In the aspect of the process, there was a part showing the participants' satisfaction towards the implementation of the training program. The results of the study are described based on their respective aspects. Each of them is elaborated as follows.

Evaluation on the Context of the Islam Education Teachers' Training Implementation

Evaluation of the context consists of several assessed sub-components, including the program planning, program implementation, program needs, the vision and mission distribution, administration of participants and Widyaiswara, training facilities, training classroom atmosphere, and training environment atmosphere. The evaluation of the context was assessed by the Widyaiswara, the organizers, and the researchers by conducting observation and documentation. The distribution of the context component assessment with the Widyaiswara as the respondents is shown in Figure 1.

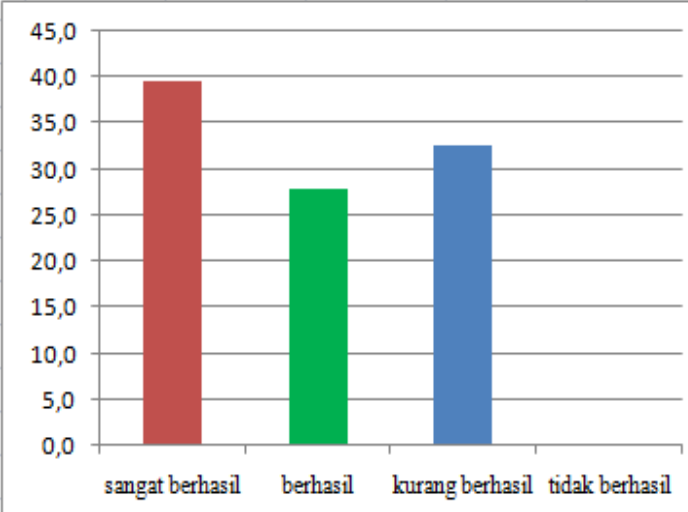

Figure 1. Distribution of Answers on the Context Evaluation (Widyaiswara Respondents)

The information of the context components is explained as follows. The term sangat berhasil means very successful, berhasil means successful, kurang berhasil means less successful, and tidak berbasil means not successful.
Figure 1 shows the distribution of answers on the context evaluation of the implementation of the Islam education teachers' training program. There are $39.5 \%$ of the Widyaiswara respondents who assess that the program is very successful. The other $27.9 \%$ say it is successful, while there are $32.6 \%$ of Widyaiswara, who states that the context of the program is not successful. Furthermore, the distribution of answers on the context evaluation based on the questionnaires which were distributed to the program organizers as the respondents is presented in Figure 2.

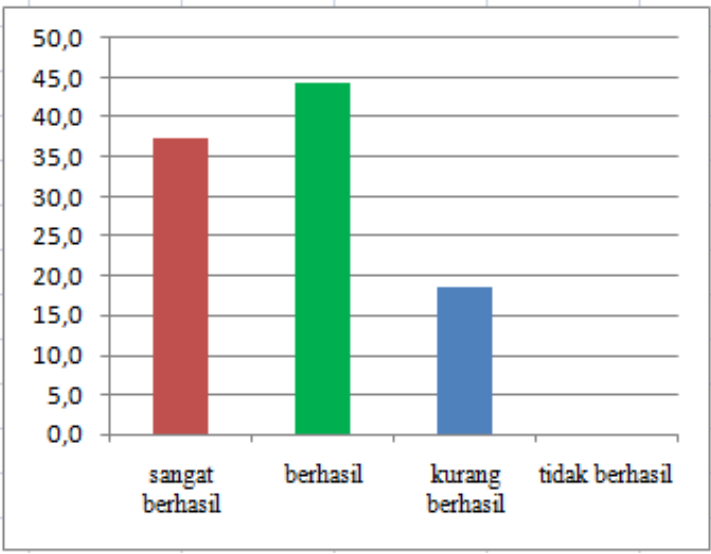

Figure 2. Distribution of Answers on the

Context Evaluation (Organizers Respondents)

Figure 2 shows that $44.2 \%$ of the organizers state that the implementation of the Islam education teachers' training program in terms of the context aspect is included in the successful category. The success is achieved in the sub-components of program planning, training facilities, and training classroom atmosphere. The very successful category is stated by $37.2 \%$ of the program organizers. In comparison, $18.6 \%$ of the organizers state that the program was less successful in terms of the context component.

The results of the assessment conducted through the observation and documentation by the researchers show that the implementation of the Islam education teachers' training program is included in the very successful category, obtaining a per- 
centage of $41.9 \%$ and $32.6 \%$, respectively. In the successful category, the percentage is $41.9 \%$ and $46.6 \%$, respectively. The less successful category obtains a percentage of $16.3 \%$ and $20.9 \%$, respectively. The distribution of the observation and documentation results can be seen in Figure 3.

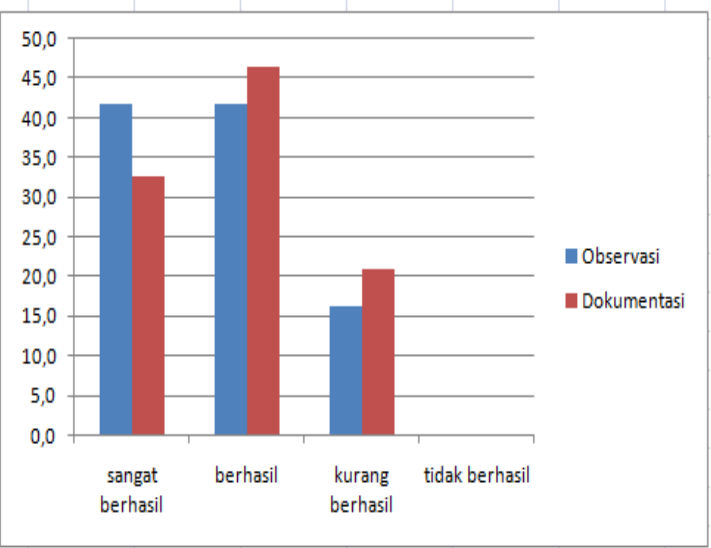

Figure 3. Context Evaluation Results (Observation and Documentation by the Researchers)

In general, the results of the study with the Widyaiswara and program organizers as the respondents and then the observation and documentation activities on the context aspect of the Islam education teachers' training program obtain a mean score of 3.15 , which is included in the successful category. Therefore, it can be concluded that the context of the implementation of the Islam education teachers' training program is in accordance with what is expected.

Evaluation on the Input of the Islam Education Teachers' Training Implementation

Evaluation of the input component is obtained from the measurement of several sub-components, including the administration of the participants and Widyaiswara, training environment, training facilities, availability of training equipment, and the atmosphere of the training environment. The distribution of answers to the input component from the Widyaiswara, organizers, and participants as the respondents is shown in Figure 4.

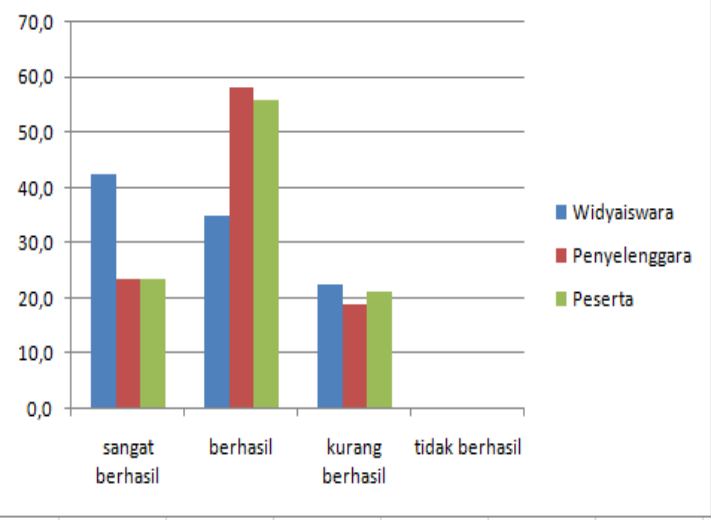

Figure 4. Distribution of Answers on the Input Evaluation

Figure 4 shows the distribution of the respondents' answers regarding the aspect of input evaluation. As many as 42.5\% of Widyaiswara state that the input aspect of the implementation of the Islam education teachers' training program is very successful. In addition, $23.3 \%$ of the organizers ( $p e-$ nyelenggara) and $23.3 \%$ of the training participants (peserta) also state that the implementation of the program in terms of the input aspect is very successful. Furthermore, $35.5 \%, 58.1 \%$, and $55.8 \%$ of the three groups of respondents state that the input aspect is classified as successful. The less successful category is chosen by $22.5 \%$, $18.6 \%$, and $20.9 \%$ of the respondents from the three different groups. In general, the answers of the respondents obtain an average score of 3.04 , which is included in the category of very successful. Thus, it indicates that the administration of participants and Widyaiswara, the training environment, training facilities, the availability of training equipment, and also the atmosphere of the training environment in terms of the input aspect are classified as very good.

Evaluation on the Process of the Islam Education Teachers' Training Implementation

The process evaluation is obtained from an analysis of the process of the Islam education teachers' training program implementation. Evaluation in the process component consists of several sub-components covering the Widyaiswara motivation, teach- 
ing and learning process, development opportunities, Widyaiswara performance, use of media, management capabilities, Widyaiswara competence, and participant assessment. In addition, the process component can also show the reaction or satisfaction of the participants in the implementation of the Islam education teachers' training program. Evaluation of this component is conducted by using a questionnaire, observation sheet, and documentation sheet. Questionnaires were distributed to the Widyaiswara, the organizers, and the participants. Observations and documentation were carried out by the researchers themselves. The results of the assessment of the process component using questionnaires are shown in Figure 5.

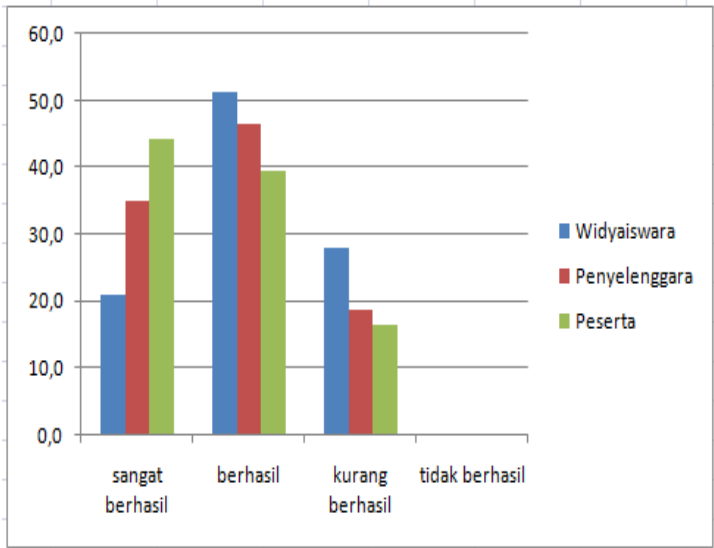

Figure 5. Distribution of Answers on the Process Evaluation Using Questionnaires

Figure 5 shows that the implementation of the Islam education teachers training program in the religious education and training center in Palembang with the Widyaiswara as the respondents on the process aspect is included in the successful category with a percentage of $51.25 \%$. The organizers' answers for the four categories in a row obtain a percentage of $34.9 \%$, $46.7 \%, 18.6 \%$, and $0 \%$. The highest percentage from the organizers is in the successful category. From the participant respondents, the percentage of the very successful category is $44.2 \%$, the successful category is $39.5 \%$, and the less successful category is $16.3 \%$. Process evaluation with the participants as the respondents is in- cluded in the very successful category. The success of the process aspect is found in the sub-components of the conducive teaching and learning process, Widyaiswara performance, development opportunities, and the use of various media. Meanwhile, the lack of success is in the sub-component of a lack of motivation from the Widyaiswara. Overall, the process evaluation is classified as very successful because it obtains an average score of 3.15. In addition, the results of the process evaluation analysis based on the observations and documentation conducted by the researchers can be seen in Figure 6 .

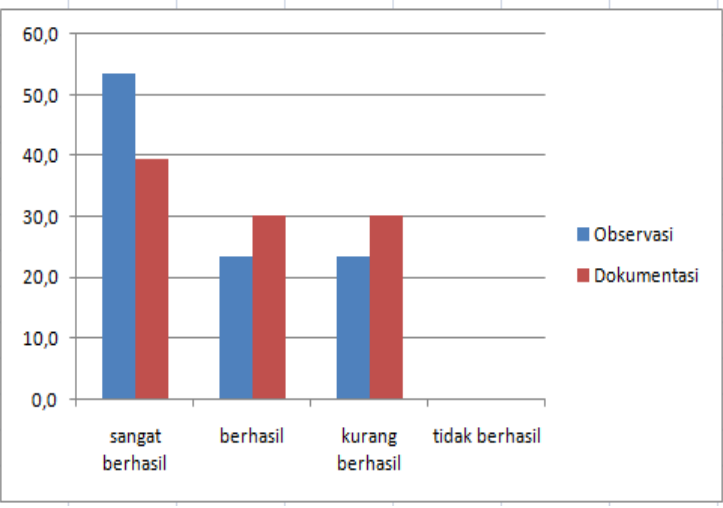

Figure 6. Observation dan Documentation

Results of the Training Program

These results indicate that the implementation of Islam education teachers' training program in the religious education and training center in Palembang in the aspect of process using observation and documentation is included in the category of very successful. The observation obtains a greater percentage than the documentation with a percentage of $53.5 \%$ for observation and $39.5 \%$ for the results of the documentation. Success is found in the subcomponents of good management skills, and the assessment from the participants who fulfill the objective assessment criteria. In the category of successful, the observation obtains a smaller percentage than the documentation with a percentage of $23.3 \%$ for observation and $30.2 \%$ for documentation. In the less successful category, the percentage obtained is the same as the percentage in the successful category, which is 
$23.3 \%$ and $30.2 \%$. Lack of success is shown in the sub-component of the lack of competence of the Widyaiswara. Whereas the unsuccessful category obtains $0 \%$, meaning that no respondent states that the observation and documentation are unsuccessful.

The results of this study indicate that the implementation of the Islam eductaion teachers' training program in the religious education and training center in Palembang in terms of process aspect is included in the category of successful. It means the subcomponents of the process are fulfilled, namely the conducive teaching and learning process, Widyaiswara performance, development opportunities, the use of various media, good management skills, and assessment from the participants who fulfill the objective assessment criteria.

In addition, the process component can also show the participants' satisfaction towards the implementation of the Islam education teachers' training program. As many as $39.5 \%$ of the training participants express that they are very satisfied with the implementation of the Islam education teachers' training program at the religious education and training center in Palembang. As many as $41.9 \%$ of the training participants express that they are satisfied with the implementation of the training. The less satisfied category obtains a percentage of $18.6 \%$. There are no participants who express dissatisfaction with the implementation of Islam education teachers' training. It means that most participants are satisfied with the implementation of the Islam education teachers' training at the religious education and training center in Palembang.

Evaluation on the Product of the Islam Education Teachers' Training Implementation

The product component consists of three subcomponents, namely the production of the teaching materials, the production of the evaluation equipment, and the production of the learning products. The results of the product component data analysis are presented in Table 4.
Table 4. Product Evaluation Distribution

\begin{tabular}{lcc}
\hline \multirow{2}{*}{ Category } & \multicolumn{2}{c}{ Respondents (\%) } \\
\cline { 2 - 3 } & Participants & Researchers \\
\hline Very Successful & 44.2 & 48.8 \\
Successful & 39.5 & 41.9 \\
Less Successful & 16.3 & 9.3 \\
Unsuccessful & 0.0 & 0.0 \\
\hline
\end{tabular}

The distribution of product component evaluation by the training participants obtains a percentage of $44.2 \%$, which is classified in the very successful category. The percentage of successful, less successful, and unsuccessful categories is $39.5 \%$, $16.3 \%$, and $0 \%$, respectively. The results of documentation conducted by the researchers obtain $48.8 \%$ for the very successful category, $41.9 \%$ for the successful category, $9.3 \%$ for the less successful category, and $0 \%$ for the unsuccessful category. It indicates that the evaluation of the product of the Islam education teachers' training program at the religious education and training center in Palembang is included in the very successful category. This success can be seen from the fulfillment of the three product evaluation sub-components.

Further, an analysis based on the average of each component is done to determine the success of the evaluation using the success criteria of Mardapi (2012, p. 162). The analysis results are shown in Table 5.

Table 5. Evaluation Results of Each Component

\begin{tabular}{ccc}
\hline Component & Average & Category \\
\hline Context & 3.15 & Very Successful \\
Input & 3.04 & Very Successful \\
Process & 3.15 & Very Successful \\
Product & 3.34 & Very Successful \\
\hline
\end{tabular}

Table 5 shows that the average of the context evaluation was at 3.15 , and the average of the input evaluation was at 3.04. The average of the process and product are 3.15 and 3.34, respectively. As the average score of the four components is more than 3 , according to the success criteria of the evaluation, then the four components are included in the very successful category. 
The model implementation stage is a trial stage in the field where the model and its instruments, as well as the equipment, are applied with the aim of knowing whether or not the evaluation model can be used properly to evaluate the implementation of the Islam education teachers' training program. The trial subjects in this study consist of the organizers of the Islam education teachers' training program, the Widyaiswara who taught at the training program, the participants of the training program at the religious education and training center in Semarang (Central Java), the religious education and training center in Jakarta, and the religious education and training center in Palembang (South Sumatera), which consist of 150 people. The data collection instruments consist of questionnaires, observation sheets, and documentation sheets.

The data of the trial results questionnaire, observation sheets, and documentation sheets that had been collected were then analyzed quantitatively using the Exploratory Factor Analysis (EFA) and Confirmatory Factor Analysis (CFA) through the SPSS program and Lisrel 8.54. CFA is used to check the construct validity of the instrument (Miller, 1996).
The CFA results show that the suitability test of the PGPAI evaluation model meets the model's goodness of fit test criteria because the $\mathrm{p}$-value is $0.9996(\mathrm{p} \geq 0.05)$ and the RMSEA is 0.000 (RMSEA $\leq 0.08$ ) (Ghozali, 2009, p. 32; Jöreskog \& Sörbom, 1996 , p. 124). In addition, the goodness of fit index (GFI) value is 0.98 , adjusted goodness of fit index (AGFI) value is 0.96, normed fit index (NFI) value is 0.99 , and comparative fit index (CFI) 1 has a value of $\geq 0.90$, which means that the hypothetical PGPAI evaluation model meets the criteria of the model fit test. Further, the relation of component and variables of evaluation that include the PGPAI's context, input, process and product show correlational indicators with variables that have high loading factors of $\geq 0.3$ (Doll, Xia, \& Torkzadeh, 1994; Gorsuch, 1983; Tabachnick \& Fidell, 2007). This result can be interpreted as the main indicator of the latent construct of the PGPAI model that has been considered good so that it is feasible to use because it has been tested empirically. The empirical model of the PGPAI evaluation model is presented in Figure 7.

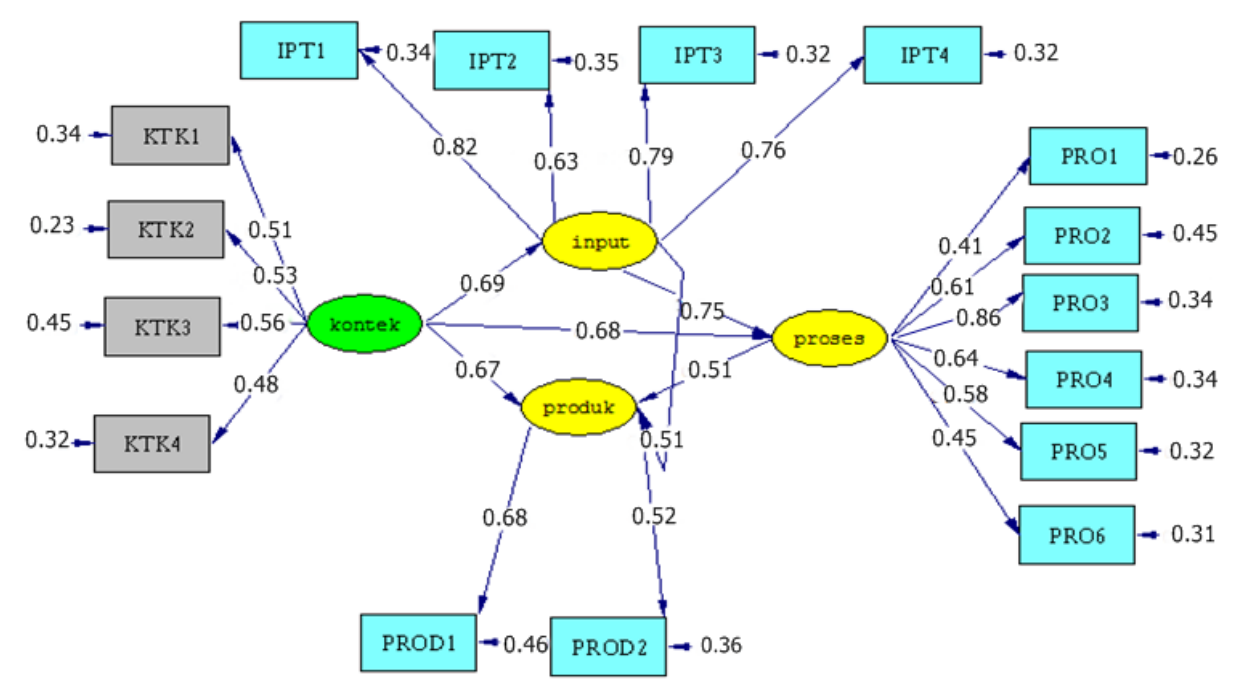

Chi-Square $=34.53, \mathrm{df}=67, \mathrm{P}-\mathrm{value}=0.99966, \mathrm{RMSEA}=0.000$

Figure 7. Empirical Model of the PGPAI Evaluation Model 
In addition, an analysis was conducted to find out the results of the evaluation of the overall implementation of the Islam education teachers' training program. The analysis results obtain an overall average of 3.17. The average score, which is more than 3 , indicates that it is in a very successful category. Based on the good average score from each component and as a whole, the evaluation results are included in the very successful category. It means that the Islam education teachers' training program at the religious education and training center in Palembang is very successful.

\section{Conclusion}

Based on the results of the data analysis, several conclusions can be drawn as follows. First, the implementation of the Islam education teachers' training program at the religious education and training center in Palembang in terms of the context component ias categorized as very successful. Second, the implementation of the training program in terms of the input component is categorized as very successful. Third, the implementation of the training program in terms of the process component is categorized as very successful, and the training participants are satisfied with the implementation of the training. Fourth, the implementation of the training program in terms of the product component is categorized as very successful. Fifth, the implementation of the Islam education teachers' training program at the religious education and training center in Palembang as a whole is very successful.

\section{References}

Arikunto, S., \& Jabar, C. S. A. (2009). Evaluasi program pendidikan: Pedoman teoritis praktis bagi praktisi pendidikan. Jakarta: Bumi Aksara.

Bhargava, A., \& Pathy, M. (2011). Perception of student teachers about teaching competencies. American International Journal of Contemporary
Research, 1(1), 77-81. Retrieved from http://www.aijcrnet.com/journals/V ol._1_No.1_July_2011/10.pdf

Borg, W. R., \& Gall, M. D. (1993). Educational research: An introduction. New York, NY: Longman.

Cennamo, K., \& Kalk, D. (2005). Real world instructional design. Belmont, CA: Thomson Wadsworth.

Doll, W. J., Xia, W., \& Torkzadeh, G. (1994). A confirmatory factor analysis of the end-user computing satisfaction instrument. MIS Quarterly, 18(4), 453-461. https://doi.org/ $10.2307 / 249524$

Ghozali, I. (2009). Aplikasi analisis multivariate dengan program SPSS. Semarang: Badan Penerbit Universitas Diponegoro.

Goldstein, I. L., \& Ford, J. K. (2002). Training in organizations: Needs assessment, development, and evaluation (4th ed.). Belmont: Wadsworth/ Thomson Learning.

Gorsuch, R. (1983). Factor analysis (2nd ed.). Hillsdale, NJ: Lawrence Erlbaum Associates.

Herzberg, F., Mausner, B., \& Snyderman, B. B. (2010). The motivation to work. New Brunswick, NJ: Transaction Publishers.

Ilukena, A. (1998). Qualities and competencies of the professional teacher. Journal for Educational Reform in Namibia, 7, 1-5. Retrieved from http://citeseerx.ist.psu.edu/viewdoc/ download?doi $=10.1 .1 .559 .7304 \&$ rep $=$ rep1\&type $=$ pdf

Jöreskog, K. G., \& Sörbom, D. (1996). Lisrel 8: User's reference guide. Englewood Cliffs, NJ: Prentice Hall.

Knowles, M. S. (1980). The modern practice of adult education: From pedagogy to andragogy. Englewood Cliffs, NJ: Prentice Hall. 
Law No. 14 of 2005 of Republic of Indonesia about Teachers and Lecturers., (2005).

Mardapi, D. (2012). Pengukuran, penilaian, dan evaluasi pendidikan. Yogyakarta: Nuha Medika.

McDavid, J. C., \& Hawthorn, L. R. L. (2006). Program evaluation and performance measurement: An introduction to practice. Thousand Oaks, CA: Sage Publication.

Miller, V. A. (1996). The history of training. In R. Craig (Ed.), The ASTD training and development handbook: $A$ guide to buman resource development. New York, NY: McGraw-Hill.

Notoatmodjo, S. (1991). Pengembangan sumber daya manusia. Jakarta: Rineka Cipta.

Phillips, J. J. (1991). Handbook of training evaluation and measurement methods. Houston, TX: Gulp Publishing Company.

Research Center for Educational Policy and Innovation. (2007). Kompetensi guru sesuai standar nasional pendidikan (SNP).
Jakarta: Institute of Research and Development, Department of National Education.

Suraji, I. (2010). Kompetensi guru Madrasah: analisis kompetensi pedagogik, kepribadian, dan sosial guru Madrasah Ibtidaiyah di Kota Pekalongan. Doctoral thesis. Universitas Islam Negeri Sunan Kalijaga, Yogyakarta.

Susatya, E. (2013). Pengembangan model pelatihan guru sekolah menengah kejuruan kelompok seni dan budaya. Jurnal Pendidikan Dan Kebudayaan, 19(1), 107-122.

Tabachnick, B. G., \& Fidell, L. S. (2007). Using multivariate statistics (4th ed.). Hillsdale: Erlbaum.

Zainuri, A. (2012). Tingkeat kompetensi guru Madrasah Ibtidaiyah Negeri (MIN) Kota Palembang. Doctoral thesis. Universitas Islam Negeri Sunan Kalijaga, Yogyakarta. 